\title{
A Study on the Experiential Aspect Markers in Weifang Dialect
}

\author{
WANG Yu-ying \\ Sun Yat-sen University, Guangzhou, China \\ LI Qiong \\ Shaanxi Normal University, Xi'an, China
}

\begin{abstract}
The aspectual system of Chinese has been the focus of research in recent years. Over a long period of time, special aspect markers “Zhe (着)” “Le (了)” “Guo (过)” in modern Chinese are produced under the grammaticized process. However, the function and the expression of aspect markers in Chinese dialects are different from those in Mandarin, which are reflected in: (1) they often have their own special aspect markers; (2) the function of aspect markers is somewhat overlapping. The purpose of this study is to describe the experiential aspects in Weifang dialect, in which the presenting pattern of "Guo1" and "Guo2" have remarkable specialties. The special feature is that the marker "Guo" is disappeared and replaced by other aspect markers. Specifically, "Guo1" is replaced by "Le1", and "Guo2" is replaced by "Hui (回)" and "Lai (来)", where "Lai" sometimes needs to co-occur with "Hui" in the sentence. This study will provide more clarity on the manifestation of the experiential aspect "Guo2", and analyze the appear condition, syntactic property and the function of "Hui" and "Lai".
\end{abstract}

Keywords: Weifang dialect, experiential aspect, aspect markers

\section{Introduction}

Weifang City is located in the middle part of the Shandong Peninsula, and has jurisdiction over the four districts of Weicheng, Kuiwen, Fangzi, and Hanting, as well as nine county-level cities of Changyi, Gaomi, Zhucheng, Wulian, Anqiu, Changle, Linqu, Qingzhou, and Shouguang. Weifang dialect belongs to the Shandong dialect of northern dialect, which is located in the middle of the eastern and western Shandong dialect region. Weifang dialect described in this article refers to the dialects of Weicheng and Kuiwen districts in the urban area. The expression of the aspectual system is basically same with that of Mandarin, but there are some distinctive features about the aspect marker. The prominent feature is that Mandarin "Guo (过)", in the corresponding expression of Weifang dialect, "Guo1" is replaced by "Le1 (了1)", while "Guo2" is expressed by two auxiliary words "Hui (回)" and "Lai (来)". Therefore, the classification of "Guo" in Weifang dialect can be recognized by forms, which is different from Mandarin.

WANG Yu-ying, graduate student, Faulty of Chinese, Sun Yat-sen University, Guangzhou, China. Research direction: psychological linguistics, second language learning.

LI Qiong, Ph.D., Associate Professor, Shaanxi Normal University, Xi'an, China. Research direction: socialinguistics, second language learning. 
According to previous studies, such as Zhang Xiaoling (1986a, 1986b), Kong Lingda (1985, 1986a, 1986b) etc., the aspect marker "Guo" in modern Chinese can be basically divided into two usages: Guo1, Guo2. Guo1 indicates the completion of a specific action, behavior or state (sticking to the core predicate), as illustrated in (1)-(3).

(1) wănfàn wǒ díquè chī-guò-le, nǐmēn bié kèqi.

dinner $1 \mathrm{sg}$ sure eat-EXP-PFV ${ }^{1}, 2 \mathrm{pl}$ NEG welcome

'I have already eaten dinner for sure, you are welcome.' (Kong, 1995)

(2) găn-dào nà, dìyī-chăng yǔjīng yăn-guò-le.

hurry at there, first part already performed-EXP-PFV.

'Hurry up there, the first part has been performed.' ( 800 words in modern Chinese)

(3) nǐ wèn guò tā méiyǒu?

2sg ask EXP 3sg NEG

'Have you asked him?' (Kong, 1995)

Guo2 indicates that a certain type of action, behavior, or state has occurred in the past, as in (4)-(6).

(4) wǒmēn zǒu guò bùshăo dìfāng.

$1 \mathrm{pl}$ go EXP many place

'We have traveled a lot.' (Kong, 1985)

(5) zhè háizì tiáopí-dehěn, gāngcái hái păo chūlái guò.

this child naughty very just now still run out EXP

'This child is very naughty and ran out just now.' (Kong, 1985)

(6) wǒ wèi tā chī guò yīwăn chăo jīdàn.

1 sg feed 3 sg eat-EXP one-bowl fry egg

'I fed it a bowl of scrambled eggs.' (Kong, 1985)

In conclusion, Guo1 is generally considered to be anperfective aspect marker, and Guo2 is a experiential aspect marker.

In Weifang dialect, the expression of Guo1 and Guo2 is special, in which Guo is replaced by other markers.

Firstly, Guo1 means the completion of the action. In Weifang dialect, aspect marker "Le (了)" indicates the corresponding meaning, as the meaning of "Le1" in Mandarin in most cases.

(7) zán chī-le-fàn jiù qù kàn diàny̌ng qù.

$1 \mathrm{pl}$ eat-PFV-food then go see movie go

'We are going to see movie after having some food.'

(8) wǒ jiào tā wèi-le chénr zài chūqù liūda.

$1 \mathrm{sg}$ ask $3 \mathrm{sg}$ feed-PFV bird then out walk

'I asked him to feed the birds before going out for a walk.'

(9) tā dăi shuōde nàxiē dōu shuō-wán-le.

3 sg want saying those all say-COMP-PFV

\footnotetext{
${ }^{1}$ Abbreviation used in the interlinear glossing are: $\mathrm{PFV}=$ perfective; $\mathrm{EXP}=$ experiential; $\mathrm{COMP}=$ complement; $\mathrm{NEG}=$ negation; $\mathrm{Q}=$ question particle; MOD = modality.
} 
'He has already said those he wanted to say.'

In modern Weifang dialects, most of the "Guo1" can be replaced by "Le1". When there is a need to emphasize the completion state, “Wan (完)” and “Bao (饱)” as complement will be added.

(10) zán chī-wán-le-fàn zài qù kàn diàny̌̌ng.

$1 \mathrm{pl}$ eat-COMP-PFV-food then go see movie

'After we have eaten then go to see movie.'

(11) qiān-wán-le shàngmiànde zì zài lái páiduì.

sign-COMP-PFV surficial name then come queue

'After signing your name, queue here.'

The similar phenomenon, that is, Guo1 is omitted or expressed in other ways can also be seen in Xiamen dialect and Fuxian dialect (Zhang, 1986).

(12) a. míngtiān chī-guò-fàn lái wǒ jiā. (Mandarin)

tomorrow eat-EXP-food come $1 \mathrm{sg}$ home

b. míngtiān chī-băo yǐhòu lái wǒ jiā. (Xiamen dialect)

tomorrow eat-COMP after come $1 \mathrm{sg}$ home

c. míngtiān chīfàn-le dào wǒ jiā. (Fuxian dialect)

tomorrow eat-PFV come $1 \mathrm{sg}$ home

'Tomorrow come to my house after dinner.'

In Weifang dialect and Fuxian dialect, both "Le" replace "Guo1" to indicate the completion of the action, but the difference is that the "Le" in Weifang dialect appears between verb and object, while in Fuxian dialect appeared after the entire VP.

\section{The Experiential Aspect “Guo2” in Weifang Dialect}

The expression of the experiential aspect marker in Weifang dialect is notably special in the tense-aspect category. In Weifang dialect, the experiential aspect marker is "Hui (回) ... Lai (来)", that is, the function of Guo2 in Mandarin is replaced by two auxiliary words, which means that experience happened in the past, that is, a certain action has been performed or a certain state has existed. Compared with the Guo1, Guo2 emphasizes a historical meaning of "experience aspect" (Dai, 1997).

(13) a. zán shuō huí zhègè shì lái.

$1 \mathrm{pl}$ talk EXP this thing EXP

b. zán búshì shuō huí zhègè shì lái?

1pl NEG talk EXP this thing EXP

'We have talked about this issue.'

(14) zhōnglóu, wǒ yīhuí yě méi qù huí.

zhenglou, 1sg once also NEG go EXP

'I didn't go to the Bell Tower once.'

(15) tā y̌̃qián dāng huí bīng lái.

3 sg past work EXP solider EXP

'He used to be a soldier.' 
(16) bié shuō yīngyǔ le, fãyŭ tā dōu xué huílái.

NEG say English MOD French 3sg also learn EXP

'Besides English, he has learned French.'

(17) shànghuí sàn-le yĭhòu, tā zài yě mù găo huí duìxiàng.

last time break up-PFV after 3sg again also NEG have EXP lover

'Since he broke up with his lover, he never have a relationship once again.'

(18) nǐmen shuí kăo huí dìȳ lái?

2pl who rank EXP first EXP

Who have ever token the first in the exam?

In affirmative sentences, such as 13a, 15, 16, "Hui" and "Lai" must appear together, and "Lai" must appear at the end of the sentence, and "hui" sticks behind the core predicate. When the object is shifted to the sentence-initial as a topic, "Hui" and "Lai" could be combined together, such as 16. In interrogative sentences, such as $13 \mathrm{~b}$ and 18, "Hui" and "Lai" also need to appear together. In negative sentences, such as 14, 17, only "Hui" appears, "Lai" is omitted. If "Lai" appears, the function of "Lai" is the modality instead of the aspect marker.

If the whole predicate is a separable word, "Hui" is located in the middle of separable word. If "Hui" is behind the separable word, it is not idiomatic, as in below.

(19) nǐ yě xià huí xiāng lái? (? nǐyěxiàxiānghuílái?)

2sg also go EXP countryside EXP

'Have you ever been to the countryside?'

In addition, "Hui" cannot co-occur with quantifier. When there is a quantifier or a time after the predicate, the expression of Guo2 in Weifang dialect is the same as Guo1, that is, replaced by Le1.

(20) tā ná-le liăng huí guànjūn. (* tānáhuíliănghuíguànjūnlái.)

3sg take-PFV two times champion

'He won the championship twice.'

(21) tā xúnsī-le yīzhèn. (* tāxúnsīhuíyīzhènlái.)

3sgt hink-PFV for a while

'He thought for a while.'

In this situation, there is no experiential aspect markers in the sentence, which is difficult to express the meaning of "ever happened or existed", so it can only be supplemented by lexical method, adding time adverbs such as "formerly (yuánxiān)" "before (yĩqián)" in order to add the perfective meaning on "Le".

(22) tā yĭqián ná-le liănghuí guànjūn.

3 sg before take-PFV two times champion

'He won two championships before.'

If there is no quantity or time phrase, Guo2 will be replaced by "Hui" and "Lai".

(23) tā qù huí wéifāng lái.

3sg go EXP Weifang EXP

'He has been to Weifang.' 


\section{(24) nǐ xúnsī huí zhègè shì lái me? \\ 2sg think EXP this thing EXP Q \\ 'Have you ever thought about this thing?'}

In conclusion, the "Hui" and "Lai" in Weifang dialect are co-occurred to express "Guo2" in Mandarin. The grammatical meanings of the two are basically the same, but there are also differences, such as "hui" and "Lai" is not co-occurred in all cases. And the grammatical meanings can only be expressed by lexicon in this situation.

\section{Experiential Aspect Marker: “Hui” and “Lai”}

\section{Grammaticalization of "Hui"}

In modern Chinese, "Hui" is used as a verb or a quantifier. "yìhuí (一回)" means "one time." This paper considers that the aspect marker "Hui" in Weifang dialect grammaticalizes from the quantifier "Hui". Because the basic usage of experiential aspect is defined as "a certain type of event occurred at least once in a period of time" (Dahl, 1985, p. 139), and "Hui" originally means "once", after grammaticalization becomes an aspect marker, means "the action has happened in the past", whose grammaticalization path is different from "Guo". This phenomenon can be confirmed by event boundary theroy.

(25) tā duìxiàng wǒ jiàn (huí)lái, zhăngde qí liáoliao.

3 sg lover 1 sg meet EXP appearance very common

'I met his girlfriend once, and she looks very common.'

(26) zhèkuài bù wǒ măi (huí)lái, qí kàng zào.

This cloth 1sg buy EXP very resist mill

'I have ever bought this cloth which is very wear-resistant.'

(27) nàgè shì wǒ zhēnshì hòuhuǐ lái.

that event 1 sg really regret EXP

'I really regret about that.'

In (26) there is no "Hui". If added, that is "nàgèshìwǒzhēnshìhòuhuǐhuílái", means "I have regretted for that once". Because Mandarin "Guo2" is unbounded while "Hui" is still in the process of grammaticalization, reserving the meaning of "once". In the (24) and (25), "meet" and "buy"is bounded, because the conclusion (appearance, quality) can be obtained after "once", there is no need to clarify the times and the meaning is not changed with "Hui".

(28) nàgè shì zán qiángdiào huílái me? (? nàgèshìzánqiángdiàolái me?)

that issue $1 \mathrm{pl}$ emphasis EXP MOD

'Have we emphasized this issue?'

The former sentence has higher acceptability, because the rhetorical question means "this issue has been emphasized once".

In addition, the word order of "Hui" in Weifang dialect and "Guo2" in Mandarin is different in some cases, reflecting the aspect marker "Hui" is grammaticalized from the quantifier.

(29) tā cónglái méi gěi nǐ huí dōngxī. (? tācóngláiméigěihuínǐdōngxī.) 
3sg never NEG give 2sg EXP thing

'He never gave you anything.'

Furthermore, according to Meng Shujuan (2001), in the Zibo dialect which is adjacent to Weifang, "yìhuí (一回)" can still be expressed in sentences as aspect marker.

(30) ménrìshà chī yìhuí píngguǒ lái.

before eat EXP apple EXP

'Have ever eaten apples before.'

Above evidences indicate that the grammaticalization path of the aspect mark "Hui", which is grammaticalized from the time qualifier "yìhuí" meaning that it happened once before.

\section{The Function of "Lai"}

In previous studies, aspect marker "Lai" in Weifang dialect is usually considered as an auxiliary particle (Cao, 1995, p. 98). In a wide spread of dialects, "Lai" is used to be experiential aspect marker, such as Meixian dialect (Lin, 1997), Wubao dialect (Xue, 1980), Yangquan dialect (Li, 2001), Fuyang dialect (Zhang, 2011), Fenyang dialect (Li, 2011), Shanggao dialect (Luo, 2013), Qingxu dialect (Zhou, 2013), Suzhou dialect (Yuli, 2015), etc.. The main grammatical meaning of "Lai" is "affirming that something has changed in the past time" or "indicating that an event or process has occurred in the past" (Liang, 2004, p. 333). The former meaning corresponds to "Le2" and "Lai1", and the latter meaning corresponds to "Lai2".

Liu Kun (2011) divides the auxiliary particle "Lai" in Weifang dialect into three categories according to its function and meaning, which are represented by "Lai1", "Lai2", and "Lai3". Among them, "Lai1" represents the speaker subjectively considered that the action occurred in the near past and has an impact on the real context, which is somewhat similar to "Le" in Mandarin; "Lai2" means that the speaker subjectively believes that the action occurred in the far past and has an impact on the real context, which is similar to the auxiliary particle "Guo2" in Mandarin; "Lai3" is more grammaticalized, expressing modality (Liu, 2011). "Lai1" is showed below.

(31) wǒ qù chīfàn lái.

$1 \mathrm{sg}$ go eat EXP

'I went to eat.'

(32) wǒ shàng tā jiā lái.

1 sg go 3 sg home EXP

'I went to his house.'

Liu Kun's classification of "Lai1" and "Lai2" is mainly based on the action time, where the distinction between "Lai1" and "Lai2" is uncertain. However, it is sure that the appearance of "Hui" expresses a far past, while the "Lai" in this sentence must be "Lai2", and the meaning of "Lai...Hui" means "Guo2" in Mandarin. If the event or behavior occurred in the recent past, "Hui" should be omitted.

(33) zuótiān tā cái xǐ lái. (* zuótiāntācáixǐhuílái.)

yesterday 3 sg just wash EXP

'He just washed yesterday.' 
The sentence with "Hui" have something wrong in semantics, because "Hui" cannot express recent past. Moreover, "Hui" always co-occurs with uncertain time or no time instead of specific time, as in below.

(34) a. tā yuánxiān dāng huí bīng lái.

3 sg before do EXP soldier EXP

'He used to be a soldier.'

b. ? tā qùnián dāng huí bīng lái.

3sg last year do EXP soldier EXP

c. *tā shànglǐbài dāng huí bīng lái.

3sg last week do EXP soldier EXP

From the above examples, as the time adverb is closer to the time of speaking, or becomes more specific, the acceptability of the sentence is lower. But the question is , whether the aspect marker is "Lai2" without "hui"? In other words, if there is no "Hui", did the event certainly happened in the recent past?

This paper believe that sometimes without the "Hui", the aspect mark is still "Lai2". As shown in (25)-(26) and (27) respectively. In the (25)-(26), when "Hui" is omitted and no specific time, the experiential aspect marker is "Lai2", because "meet" and "buy" after once can draw conclusions about appearance and quality. The "regret" in (27) is a continuous action, which is difficult to decide the specific time. Hence, "wǒhòuhuilái " means "have ever undergone regret", and "wǒhòuhuǐhuílái" have ambiguity.

(35) a. nǐ zhè bèizĩ yīnwéi shénme shì hòuhuǐ huílái me?

1 sg this life because what thing regret EXP Q

'Have you ever regreted anything for your life?'

b. zhèshì nǐ hòuhuǐ huílái me?

this thing $1 \mathrm{sg}$ regret EXP Q

'Have you ever regreted for this thing?'

(35a) indicates whether the speaker has ever done the "regret" behavior, and (35b) indicates whether regretted for a specific thing.

In addition, there is a case that conforms to without "Hui" as experiential aspect marker, that is, the time adverb appears to make the sentence have the meaning of experience.

(36) tā qǔzăo-yĭqián kāi xiăomàibù lái.

3sg long time ago open store EXP

'He opened a store a long time ago.'

The meaning and function of this "Lai" need to have a further discussion on "Lail". This research will be done in the future because of the length and the theme of this paper. It can be sure that the usage of "Lail" is more sophisticated than that of "Lai2".

\section{Conclusion}

In many Chinese dialects, the experiential aspect marker (Guo2) usually has its own markers, while Weifang dialect is special that both Guo1 and Guo2 have its own markers, that is, the function of Guo in Weifang dialect is replaces by other words. Even under the circumstance that Mandarin has a wider spread influence, "Guo1" and "Guo2" have never been seen in the everyday spoken Weifang dialect. 
In the Weifang dialect, there are some distinctive features about the experiential aspect marker. The first is that "Guo" in Mandarin is replaced by other corresponding words in Weifang dialect. The second is that "Guo2" is replaced by two auxiliary words "Hui" and "Lai" whose appearance is different in different cases, which is unique among dialects.

\section{References}

Cao, G. S. (1995). Auxiliary words in modern Chinese. Beijing: Language \& Culture Press.

Chen, Q. R. (2008). Typological perspectives on the study of Chinese aspectual system. Beijing: Commercial Press.

Chen, Z. Y., \& Li, Y. H. (2013). EXPER guo 2 and repeatability. Chinese Teaching in the world, 3, 331-345.

Dahl, O. (1985). Tense and aspect system. Bath, England: The Bath Press.

Kong, L. (1986). On aspect markers 'guo1' and 'guo2'. Journal of Anhui Normal University, 4, 115.

Li, C. X. (2001). The aspectual functions of modal particles in Yangquan dialect. Journal of Shanxi University (Philosophy and Social Sciences), (01), 65-68.

Li, W. F. (2011). The aspect marker "lai" in Fenyang dialect of Shaanxi. Journal of Language and Literature Studies, $17,89-92$.

Liang, Y. F. (2004). The origins and emergent time of the aspectual expression of lai. Chinese Language, 4, 333-342.

Liu, K. (2011). Research on auxiliary "Lai” in Weifang dialect. Shanghai: Shanghai Normal University.

Lü, S. X. et al. (1980). 800 words of modern Chinese. Beijing: Commercial Press.

Luo, R. H. (2013). Experiential aspect " lai "and perfect aspect "guo" in gan dialect (Shanggao). Studies of the Chinese Language, 4, 316-318.

Meng, S. J. (2001). Research on Zibo dialect's aspectual system and related function words. Shantou: Shantou University.

Qian, Z. Y., \& Luo, F. T. (1992). Weifang dialect. Weifang: Weifang Press and Publication Bureau.

Xue, M. S. (1980). The special usage of "Lai" in Wubao dialect. Studies of the Chinese Language, 5.

Yu, L. X. (2015). Research on tense auxiliary word "Lai" in Suzhou dialect of northern Anhui. Journal of West Anhui University, 6,95-98.

Zhang, Q. M. (2011). Research on the tense auxiliary word "lai" in Fuyang dialect. Big Stage, 2, 184-185.

Zhang, X. L. (1986). On the relationship between "Guo" and "Le". Language Teaching and Linguistic Studies, 1, 48-57.

Zhen, Z. (2011). A study on "zhe" and "guo" in LiaozhaiLiqu and Zibo dialect. Journal of Qiqihar University (Philosophy \& Social Science Edition), 5, 23-26.

Zhou, W. R. (2013). The Auxiliary “lai” in the dialects of Qingxu dialect. Harbin: Harbin Normal University. 